\title{
The Effects of Injected Geophyte Plant (Sternbergia candida) Extract on the Hemato-Immunological Parameters in Gilthead Seabream, Sparus aurata (L. 1758)
}

\author{
Esin $\mathrm{Baba}^{1^{*}}$ \\ https://orcid.org/0000-0002-4693-7777 \\ Gülşen Uluköy ${ }^{1}$ \\ https://orcid.org/ 0000-0002-7759-4279

\section{Ramazan Mammadov 2 \\ https://orcid.org/ 0000-0003-2218-5336}

${ }^{1}$ Mugla Sıtkı Kocman University, Faculty of Fisheries, Department of Aquaculture, Diseases Division 48000, Mugla, Turkey; ${ }^{2}$ Mugla Sıtkı Kocman University, Faculty of Science, Department of Molecular Biology and Genetics, Mugla, Turkey.

Editor-in-Chief: Alexandre Rasi Aoki

Associate Editor: Najeh Maissar Khalil

Received: 2021.01.26; Accepted: 2021.09.24.

*Correspondence: esinbaba48@hotmail.com; Tel.: +90-252 2111904 (E. B.).

\section{HIGHLIGHTS}

- The plant extract show enhancement on non-specific immune response in gilthead seabream.

- Short term application of Sternbergia candida give a valuable result for fish farms.

- This study result obtained in natural environmental condition in a gilthead seabream farm.

\begin{abstract}
This study investigated effects of a geophyte plant extract (Sternbergia candida) on some hematoimmunological parameters in gilthead seabream, Sparus aurata (L. 1758). To serve this purpose, the plant was collected and extracted in ethanol solvent. A total 300 fish were used in experiment. Three groups were designed including control group, $0.5 \mathrm{mg} /$ fish and $2 \mathrm{mg} / \mathrm{fish}$ and plant extract was given by intraperitoneal injection. Following injections on the 1st, 7th, 14th, 21st, 28th and 35th days, blood samples were collected from each group. Some of the hemato-immunological parameters in serum and blood samples such as, phagocytic activity (NBT (+) cells), total leukocyte level, lysozyme activity, total protein, hematocrit level and the differential leucocyte were examined. Present results show that intraperitoneal injection of $S$. candida plant extract increases some non-specific immune parameters. In the determination of the non-specific immune responses of the gilthead seabream, blood samples collected from $2 \mathrm{mg} /$ fish group indicated that maximum levels of pre-determined parameters were reached on days 7, 14, and 21 following the injection. According to these finding, administration of geophyte plant is suggested in seabream to improve non-specific immune response and health status.
\end{abstract}

Keywords: immunity; plant extract; Sternbergia candida; fish; injection. 


\section{INTRODUCTION}

Gilthead seabream (S. aurata (L. 1758)) is an eminently marine species, which is widely common in aquaculture activity worldwide including Turkey. However, stocking density in fish farms has led to problems such as environmental damage, increased numbers of opportunistic microorganisms and stress conditions. Such adverse events may compromise the growth and health of fish and make animals more susceptible to infections and disease, causing significant economic losses [1]. For modern processes of aquaculture, prophylactic methods have become indispensable since significant progress has been made by stimulating the fish immune system through prophylactic methods [2]. Currently, the main prophylactic measures available for farmed fish include vaccination, probiotics and immunostimulant [3]. Throughout human history, a good diversity of herbs has been utilized around the world to make improvements on human health, help provide resistance against multiple infections or treat diseases [4]. In addition, they can be used as an alternative to chemotherapy and vaccination [5].

Natural products can be used as prevention against stress and infectious diseases as well as therapeutic and growth promoters [6]. The idea was to use natural products which are friendly to the environment to strengthen the immune system of fish $[7,8,9,10]$. S. candida was chosen for this study because it is an endemic geophyte species and has not been tested on fish. $S$. candida is a significant geophyte plant. Plant extract is obtained from $S$. candida bulbous belonging to Amaryllidaceae family [11]. It wildly grows in Turkey, Africa, Asia and Europe [12]. All species of this family are known to have immunostimulant, antimicrobial, antiviral and antitumor activities also to enhance immune response $[13,14]$ but the activity of this plant have not yet been researched in fish species. In this sense, numerous efforts have been made to evaluate the immunostimulant effects of natural products in different fish species. It has been reported that several natural products, such as Trigonella foenum graceum [15, 16], Nigella sativa [17], Excoecaria agallocha [18], Ducrasia anethifolia [19], Mentha piperita [20], Camellia sinensis [21] and Aloe vera [22] enhance the nonspecific immune response and disease resistance in various fish species.

It is important to underline the determination of hematological parameters for diagnosis of disease and abnormal situations. At same time, enhancement of fish immune system is necessary by using immunostimulant [23, 24, 25]. The using hematological analysis of blood in alive fish is important because it provides an evaluation of its health [26, 27, 28].

The aim of the present study was to determine the effects of injected $S$. candida geophyte plant extract on non-specific immune system in $S$. aurata. The potential use of this plant as a stimulant in fish immune system was investigated.

\section{MATERIAL AND METHODS}

\section{Plant extract}

S. candida was obtained from the natural area in Mugla, Turkey. The bulb parts of the plant were washed with distilled water then cut into small pieces. The bulb pieces were air dried in a shady area for two weeks before being grounded to powder (200-250 g dry weight) and extracted with $500 \mathrm{~mL}$ balloon flasks of ethyl alcohol for $24 \mathrm{~h}$ according to the methods of Lee and coauthors [29]. The extract was filtered with Whatman filter paper $(0.45 \mu \mathrm{m})$. This process was repeated three times. The solvent was evaporated from the crude extract using lyophilizator and extract kept at $4{ }^{\circ} \mathrm{C}$ in dark bottles until further use.

\section{Fish and trial design}

The marine fish, gilthead seabream, $S$. aurata $(112.00 \pm 1.5 \mathrm{~g})$ were provided from a commercial fish farm (Mugla-Bodrum in the facilities of Kilic Seafish Import Export Corporation at Guvercinlik, Turkey). The study was conducted by following Mugla Sıtkı Koçman University approved ethical rules. The fish were maintained in $1500 \mathrm{~L}$ aerated fiberglass tanks. The water quality was recorded by using multiprobe (YSI 556 MPS) and measured as follows: temperature $23^{\circ} \mathrm{C}, \mathrm{pH} 7.6$ salinity $\% 037$ and dissolved oxygen $7.5 \mathrm{mg} / \mathrm{L}$. A total of 300 fish were used in the experiment. After two weeks acclimatization periods, fish were randomly divided into nine fiberglass tanks in 3 duplicate groups at a stocking density of 50 fish/tank. Sterile phosphate buffered saline (PBS) soluble geophyte plant extract (S. candida) was applied to each fish by intraperitoneal injection method. The first and second group inoculated $0.1 \mathrm{~mL}$ of the geophyte plant extract in different concentrations (first group: $0.5 \mathrm{mg} / \mathrm{fish}$; second group: $2 \mathrm{mg} / \mathrm{fish}$ ) by injection method. The control group was inoculated only PBS in the same volume $(0.1 \mathrm{~mL})$. Sampling was done on the 1st, 7th, 14th, 21st, 28th and 35th days after intraperitoneal injection. 


\section{Serum and Blood Cells}

Five gilthead seabreams from each individual tank were randomly collected and anaesthetized with phenoxyethanol. The blood samples were taken from caudal vein. Some of the blood was put into an Eppendorf tube for analysis. The other portion of blood samples were kept at $4{ }^{\circ} \mathrm{C}$ for overnight and later the serum was collected after centrifugation $\left(3500 \mathrm{~g}, 5 \mathrm{~min}, 4^{\circ} \mathrm{C}\right)$. Serum samples were stored at $-80^{\circ} \mathrm{C}$ until use for other analysis.

\section{Nitro blue tetrazolium (NBT) assay}

Respiratory burst activity was determined according to the method described by Anderson and coauthors [30]. Briefly, NBT suspension $(0.2 \%)$ was prepared with sterile saline solution $(0.85 \%)$. Thereafter, $50 \mu \mathrm{L}$ of blood was dropped onto a coverslip and incubated for $30 \mathrm{~min}$ at $25^{\circ} \mathrm{C}$. The details of each stages were described in our previous paper [31].

\section{Lysozyme activity}

The serum lysozyme activity was determined in turbidimetric assay with minor modification [32, 33]. In brief, $25 \mu \mathrm{L}$ of fish serum were added $175 \mu \mathrm{L}$ Micrococcus lysodeikticus suspensions in duplicate well of a microplate. The reaction incubated at $22{ }^{\circ} \mathrm{C}$ and absorbance $490 \mathrm{~nm}$ was carried out after 0.5 and $4.5 \mathrm{~min}$ using an ELISA microplate reader. A unit of lysozyme activity was defined as a decrease in absorbance of $0.001 / \mathrm{min}$.

\section{Total protein}

The Bradford assay for total protein was measured according to Bradford [34]. The reaction was carried out in a 96 well plate. The absorbance was read at $595 \mathrm{~nm}$ by a multi-scan microplate reader. The standard solution was prepared using bovine serum albumin. Serum total protein concentration were expressed as $\mathrm{mg} / \mathrm{mL}$.

\section{Hematological parameters}

Hematocrit (\%), total white blood cells (WBC, $10^{3}$ cell $/ \mathrm{mm}^{3}$ ) count and differential leukocyte count (monocyte, neutrophil, eosinophil, lymphocyte (\%)) was calculated as hematological parameters. Percent hematocrit level was determined with microcentrifuge technique, using heparinized capillary tubes. For WBC count Natt-Herrick solution method was used. Total leukocyte amounts were counted using Neubauer counting chamber. Differential leukocyte count was made in peripheral blood smears stained by MayGrunwald and Giemsa stains and percentages of leukocyte types were calculated [35, 36].

\section{Statistical analysis}

Effects of plant extract on hemato-immunological parameters were expressed as the arithmetic means standard error (SE) by using Tukey's pairwise multiple comparison test of variance (ANOVA). Differences were considered significant at $P<0.05$.

\section{RESULTS}

\section{NBT-Positive cell count}

NBT positive cell counts of samples determined that there were differences (Figure 1) among the trial groups and the control group on certain days $(P<0.05)$. The respiratory burst activity significantly increased in all the experiment groups during the trial period. The highest activity was recorded at days 7 th, 14 th and $21 \mathrm{st}$ in the $2 \mathrm{mg} /$ fish group. 


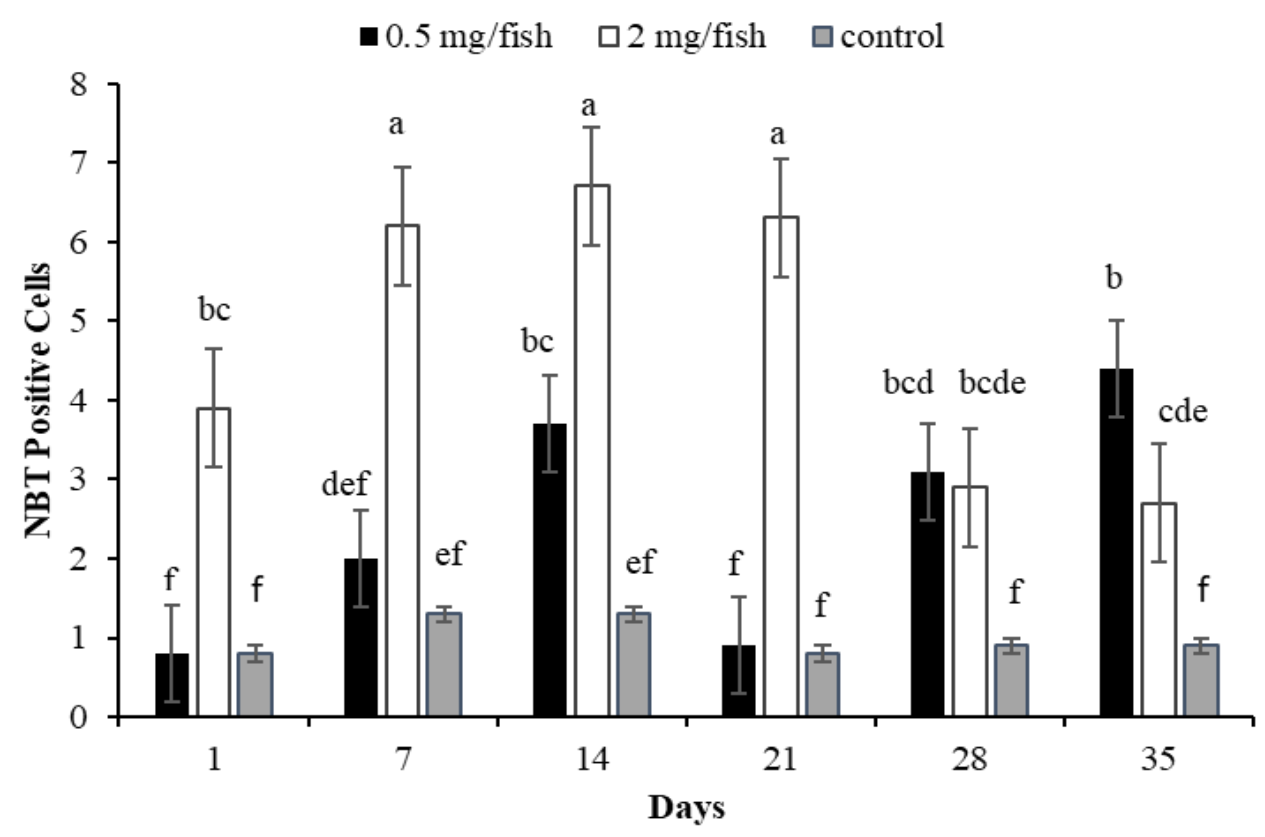

Figure 1. Effects of plant extract on the number of NBT-positive cells of seabream. Vertical lines are mean \pm SEM [SEM.: standard error mean]. Different letters represent significant differences at $P<0.05$.

\section{Lysozyme activity}

The effect of plant extract injected fish on the lysozyme activity in serum is exhibited in Figure 2. The serum lysozyme activity was detected to be higher in $2 \mathrm{mg} /$ fish concentration of plant extract injected fish serum than in $0.5 \mathrm{mg} / \mathrm{fish}$ and the control group during the experiment time. $(P<0.05)$. Among the concentrations and the days tested, the $2 \mathrm{mg} /$ fish showed the highest lysozyme activity at days 7th, 14th and 21 st.

- $0.5 \mathrm{mg} /$ fish $\quad \square 2 \mathrm{mg} / \mathrm{fi}$ sh $\quad$ in control

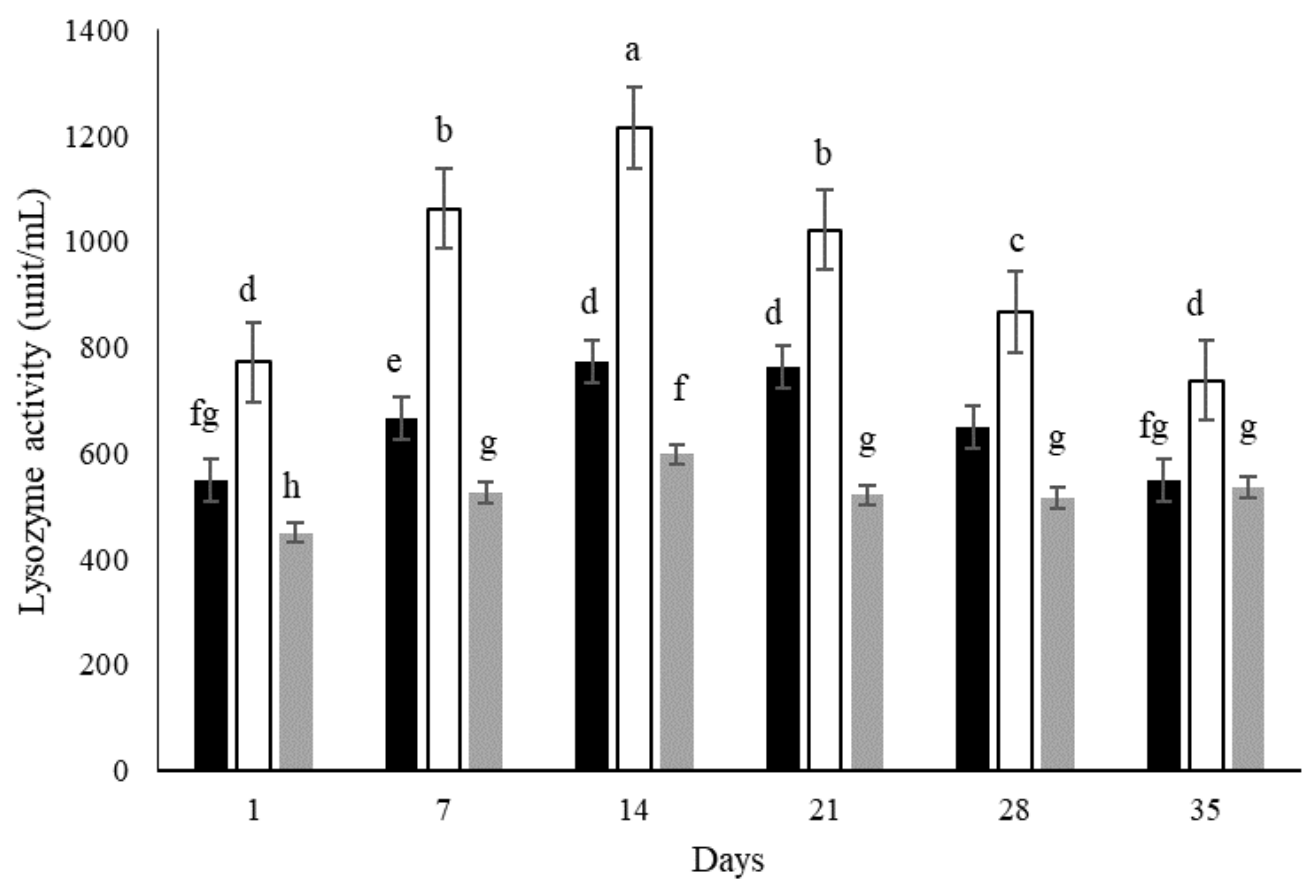

Figure 2. Changes of lysozyme activity in serum of seabream. Vertical lines are mean \pm SEM [SEM.: standard error mean]. Different letters represent significant differences at $P<0.05$.

\section{Total protein amount}

Total serum protein amount was not significantly increased $(P>0.05)$ in injected fish $(0.5$ and $2 \mathrm{mg} / \mathrm{fish})$ with plant extract as compared to control for experimental period (Figure 3). 


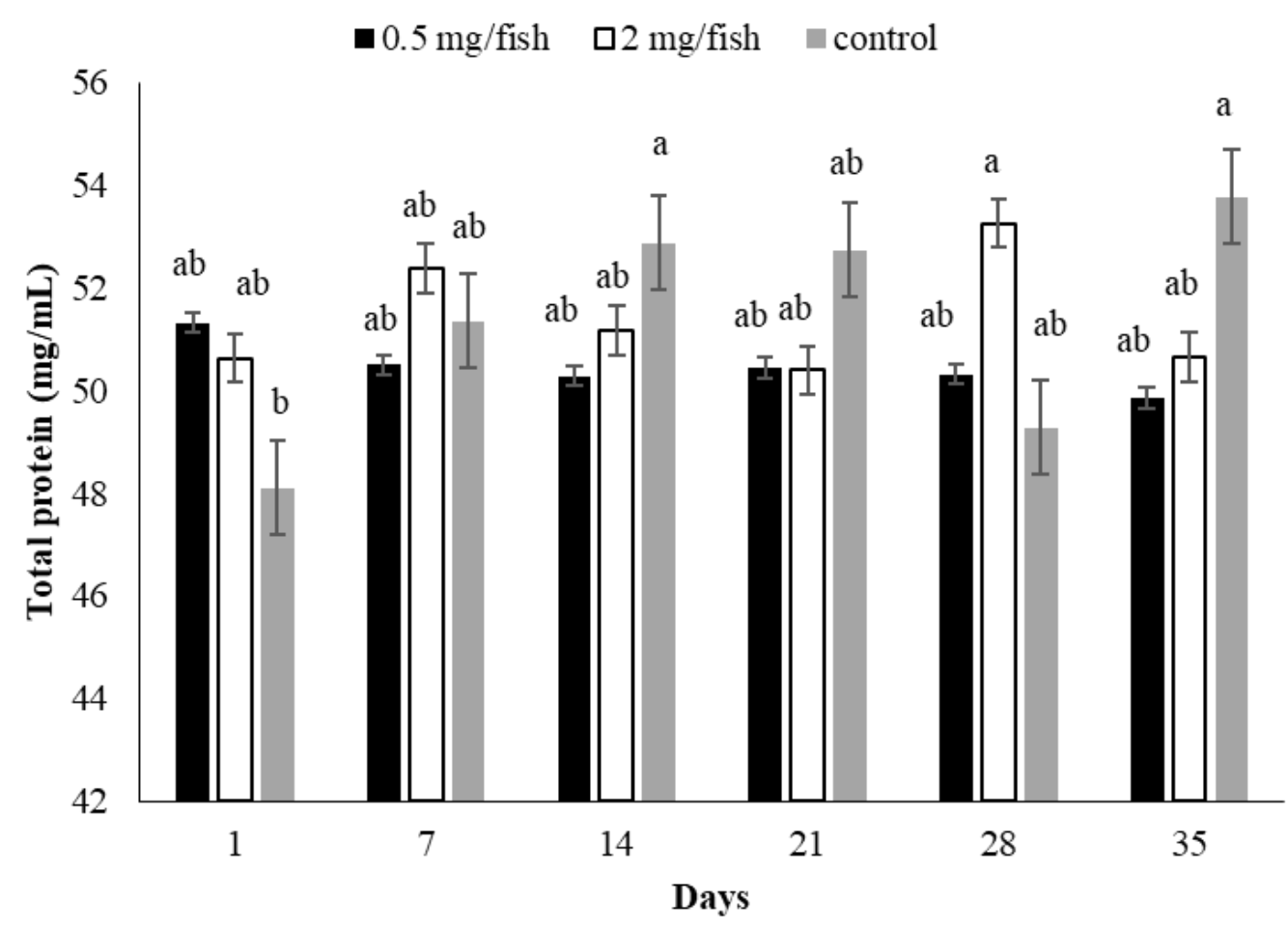

Figure 3. Effects of plant extract on total protein level in serum of sea bass. Vertical lines are mean \pm SEM [SEM:standard error mean]. Different letters represent significant differences at $\mathrm{P}<0.05$.

\section{Hematological parameters}

WBC number, especially those injected $2 \%$ concentration which showed increase $(P<0.05)$ compared to the values found in fish from the control group. On other days, it is detected that the injected plant extract had no effect on WBC of blood samples in gilthead seabream $(P>0.05)$. No significant changes $(P>0.05)$ were determined in hematocrit level (Table 1) among experimental groups compared to the control group. Besides phagocytic blood cells (monocytes, neutrophils, and eosinophils) were significantly increased ( $P<$ 0.05) in all experimental groups compared to those in the control (Table 1). The lymphocyte amount did not show much variation between the control and experimental groups. According to the recorded data in this study experimental groups showed the highest effect of monocytes, neutrophils and eosinophils on 7th, 14th and 21 st days. 
Table 1. The percentage of lymphocyte, monocyte, neutrophil, and eosinophil cells in blood samples of seabream injected plant extract.

\begin{tabular}{|c|c|c|c|c|c|c|c|}
\hline Days & Dose & WBC & M & $\mathbf{N}$ & $E$ & $\mathbf{L}$ & Hct \\
\hline \multirow[t]{3}{*}{1} & 0.5 & $32.14 \pm 4.08^{h}$ & $4.5 \pm 0.48^{\text {def }}$ & $5.10 \pm 0.49^{b c}$ & $7.60 \pm 0.78^{\mathrm{de}}$ & $82.80 \pm 0.99^{e f}$ & $33.50 \pm 1.13^{\text {def }}$ \\
\hline & 2 & $63.12 \pm 4.27^{\mathrm{fg}}$ & $5.90 \pm 0.52^{\mathrm{bc}}$ & $5.70 \pm 0.13^{b}$ & $7.60 \pm 0.45^{\mathrm{de}}$ & $80.80 \pm 0.37^{\text {ef }}$ & $36.80 \pm 1.33^{\text {cde }}$ \\
\hline & C & $52.02 \pm 3.899$ & $4.20 \pm 0.50^{\text {def }}$ & $3.10 \pm 0.37^{e}$ & $3.40 \pm 0.35^{g}$ & $89.30 \pm 0.92^{\mathrm{abc}}$ & $28.90 \pm 1.98^{f}$ \\
\hline \multirow[t]{3}{*}{7} & 0.5 & $87.02 \pm 5.83^{\mathrm{de}}$ & $4.10 \pm 0.32^{\text {ef }}$ & $5.10 \pm 0.48^{b c}$ & $7.30 \pm 1.34^{\mathrm{de}}$ & $83.50 \pm 1.04^{\mathrm{de}}$ & $35.00 \pm 1.36^{\text {cde }}$ \\
\hline & 2 & $90.77 \pm 5.25^{\mathrm{cde}}$ & $5.50 \pm 0.69^{c d}$ & $4.90 \pm 0.28^{\mathrm{bc}}$ & $8.00 \pm 0.78^{\mathrm{de}}$ & $81.60 \pm 0.87^{e f}$ & $40.10 \pm 0.61^{b c}$ \\
\hline & C & $82.49 \pm 3.61^{\mathrm{e}}$ & $2.70 \pm 0.27^{\mathrm{gh}}$ & $2.70 \pm 0.22^{\mathrm{ef}}$ & $3.40 \pm 0.19^{g}$ & $91.40 \pm 0.62^{\mathrm{a}}$ & $36.60 \pm 1.83^{\mathrm{cde}}$ \\
\hline \multirow[t]{3}{*}{14} & 0.5 & $107.65 \pm 6.13^{b c}$ & $7.10 \pm 0.60^{\mathrm{ab}}$ & $6.10 \pm 0.92^{b}$ & $6.40 \pm 0.82^{\mathrm{ef}}$ & $80.40 \pm 1.25^{\text {ef }}$ & $36.70 \pm 1.45^{\mathrm{cde}}$ \\
\hline & 2 & $113.74 \pm 5.63^{b}$ & $8.10 \pm 0.24^{a}$ & $7.80 \pm 0.50^{\mathrm{a}}$ & $9.20 \pm 0.64^{d}$ & $74.90 \pm 1.29 \mathrm{~g}$ & $35.40 \pm 0.78^{\mathrm{cde}}$ \\
\hline & $\mathrm{C}$ & $119.21 \pm 4.63^{b}$ & $3.40 \pm 0.33^{g h t}$ & $3.20 \pm 0.24^{e}$ & $4.60 \pm 0.26^{\mathrm{fg}}$ & $88.80 \pm 0.64 \mathrm{abc}$ & $38.00 \pm 1.45^{\mathrm{bcde}}$ \\
\hline \multirow[t]{3}{*}{21} & 0.5 & $139.83 \pm 4.28^{a}$ & $5.25 \pm 0.73^{\text {cde }}$ & $4.45 \pm 0.27^{c d}$ & $25.10 \pm 1.56^{a}$ & $67.20 \pm 1.02^{h}$ & $42.20 \pm 1.89^{a b}$ \\
\hline & 2 & $115.77 \pm 4.83^{b}$ & $6.10 \pm 0.52^{b c}$ & $5.90 \pm 0.54^{b}$ & $23.05 \pm 1.89^{a}$ & $64.95 \pm 1.64^{\mathrm{h}}$ & $39.40 \pm 3.96^{b c}$ \\
\hline & C & $115.93 \pm 3.24^{b}$ & $2.60 \pm 0.33^{g h t}$ & $3.60 \pm 0.49 \mathrm{de}$ & $7.80 \pm 0.24^{\mathrm{de}}$ & $86.40 \pm 0.80^{\mathrm{cd}}$ & $38.80 \pm 0.54^{b c}$ \\
\hline \multirow[t]{3}{*}{28} & 0.5 & $86.08 \pm 4.05^{\mathrm{de}}$ & $3.20 \pm 0.38^{\text {fgh }}$ & $1.80 \pm 0.24^{\mathrm{fg}}$ & $14.80 \pm 0.53^{b}$ & $80.20 \pm 1.10^{\text {ef }}$ & $42.10 \pm 0.46^{\mathrm{ab}}$ \\
\hline & 2 & $93.30 \pm 4.20^{\text {cde }}$ & $5.20 \pm 0.24^{\text {cde }}$ & $3.40 \pm 0.16^{\mathrm{de}}$ & $11.60 \pm 0.45^{c}$ & $79.80 \pm 0.24^{\dagger}$ & $46.70 \pm 1.76^{a}$ \\
\hline & C & $75.77 \pm 4.94^{\text {ef }}$ & $2.20 \pm 0.24^{\mathrm{ghl}}$ & $1.60 \pm 0.16^{\mathrm{fg}}$ & $8.60 \pm 0.45^{\mathrm{de}}$ & $87.60 \pm 0.45^{b c}$ & $38.20 \pm 0.85^{\text {bcde }}$ \\
\hline \multirow[t]{3}{*}{35} & 0.5 & $102.96 \pm 5.06^{\mathrm{bcd}}$ & $1.80 \pm 0.24$ & $1.20 \pm 0.13^{\mathrm{g}}$ & $6.00 \pm 0.29$ ef & $91.00 \pm 0.47^{\mathrm{ab}}$ & $33.20 \pm 1.34^{\mathrm{ef}}$ \\
\hline & 2 & $107.02 \pm 4.74 \mathrm{bc}$ & $2.20 \pm 0.24 \mathrm{ghl}$ & $1.40 \pm 0.16^{g}$ & $7.00 \pm 0.36^{\text {def }}$ & $89.60 \pm 0.68 \mathrm{abc}$ & $37.30 \pm 1.03^{\text {bcde }}$ \\
\hline & C & $63.70 \pm 3.47^{\mathrm{fg}}$ & $2.00 \pm 0.29^{\text {hl }}$ & $1.40 \pm 0.16^{g}$ & $6.20 \pm 0.38^{\mathrm{ef}}$ & $90.80 \pm 0.67^{a b}$ & $38.50 \pm 1.16^{\mathrm{bcd}}$ \\
\hline
\end{tabular}

Means having different superscript letters in same column are significantly different from each other $\mathrm{P}<0.05$. (C: control, WBC: white blode cells $\left(10^{3} \mathrm{cell} / \mathrm{mm}^{3}\right), \mathrm{M}$ : monocyte (\%), N: Neutrophil (\%), E: eosinophil (\%), L: lymphocyte (\%), Hct: hematocrit (\%)).

\section{DISCUSSION}

The innate immune system components take place on the first line of fish defence against various pathogens in fresh and marine environmental conditions. The enhancement of the system is important for fish health [37, 38]. The application of herbs could enhance the immune mechanism of fish against all kind of pathogens in aquaculture [39, 40,41].

This research explored the possible effect of $S$. candida geophyte plant extract intraperitoneally injected with different concentrations on the non-specific immune system in S. aurata. Our research detected different degree of effectiveness on immunological and hematological parameters in seabream, $S$. aurata within a 35 days experimental period. Respiratory burst activity is one of important defense mechanism of innate immunity [42]. In the present study, we detected increase in the number NBT positive cells. NBT positive cell numbers reached the maximum level on the 7th, 14th and $21 \mathrm{st}$ days in the $2 \mathrm{mg} /$ fish experiment group. This is supported by the works of Anderson and coauthors [30], Anderson and Jeney [43], Chen and coauthors [44] in that NBT-positive cell numbers to increase in fish which were given immunostimulants by injection. Similar results were obtained in different fish species, such as Oreochromis niloticus [18], Mugil cephalus [21], Epinephelus coioides [45], S. aurata [16, 31]. Also, respiratory burst activity was significantly higher in seabream fish fed diets supplements with $0.1 \%$ and $1 \%$ dihydroquercetin obtained from deodar (Cedrus deodora) compared to the control [46]. In fish, lysozyme is an important bacteriolytic enzyme against pathogen invasions [47]. Our results revealed an increase in lysozyme activity in experimental groups injected with plant extract for especially certain days. Feeding 0 . niloticus with Excoecaria agallocha for 28 days led to significant in serum lysozyme activity [18]. Kakoolaki and coauthors [21] observed increases in lysozyme activity in Mugil cephalus fed with different doses of Camellia sinensis. Similarly, feeding tilapia with different concentration Aloe vera led to an increase in lysozyme activity compared to control group [22]. Moreover, Bilen and coauthors [48] documented an increased activity of lysozyme in rainbow trout fed with various concentration Pleurotus ostreatus and Urtica dioica. Similarly, elevated lysozyme activity was noted on 
Oncorhynchus mykiss [20], Salmo trutta caspius [49], Oreochromis niloticus, Oreochromis aureus [50], Cyprinus carpio [51].

The principle factor that accounts for the fluctuations in the plasmatic volume is the total amount of protein in the serum as a result of stressors [52]. This study exhibited that two concentration of $S$. candida plant extract did not alter total protein level compared to control group. In the line with this study, Baba and coauthors [31] reported that plant extract (Muscari comosum) did not change the serum total protein amount in S. aurata. Similarly, Dadras and coauthors [53] showed that dietary supplementation with two medicinal plant no alter the protein amount in the seum of Huso huso. Also, Vazirzadeh and coauthors [19] documented that Ducrasia anethifolia essential oil have no effects on serum protein level in Oncorhynchus mykiss.

In the field of aquaculture, haematological parameters are utilized as common signifiers for fish health conditions such as stress or disease [54]. Besides, in order to find out the impact of the prospective immunostimulants on the fish immune system, each of the parameters is investigated [55]. The role of white blood cell in innate immunity is well established. It constitutes the primary line of defense. As its numbers increase in parallel to other immunological parameters in the fish, it is used to determine their health status [56]. Our data showed that WBC of plant extract injected fish with $2 \%$ concentration significantly increased after 28 th days. On other days, no difference we observed in number of WBC compared to control group. The obtained results agree with those obtained in common carp [42], rainbow trout [19, 20, 58], juvenile beluga [53], Caspian brown trout [49], seabream [15, 31]. The present study, it was observed that the monocyte, neutrophil and eosinophil counts in blood samples were increased on the fish injected with $S$. candida plant extract. It has been determined that the leukocyte cells in blood reached maximum level on the 7th, 14th and 21st in experimental groups (0.5 and $2 \mathrm{mg} / \mathrm{fish})$. Overlay, hematocrit values were observed demonstrate any significant difference in all experiment groups. The hematocrit level of the fish blood is not negatively impacted by the plant extracts. In parallel with our results, hematocrit levels 0 . mykiss exhibited no alters after feeding with Ducrosia anethifolia essential oil [19]. Also, Nya and Austin [58] documented that feeding rainbow trout with garlic did not change the hematocrit level.

It is concluded that injected $S$. candida geophyte plant extract at the concentration especially $2 \mathrm{mg} /$ fish enhanced the non-specific immune system. In the light of the data obtained, the $S$. candida geophyte plant extract can be added to the feed and applied to fish under aquaculture conditions. Nevertheless, future studies are needed to determine the effects of $S$. candida geophyte plant extract on the other cultured fish species.

Funding: This research was funded by TUBITAK Career Project (104V126).

Acknowledgments: We thank Süleyman BABA for his moral support during the work.

Conflict of Interest: The authors declare that they have no conflict of interest. The funders had no role in the design of the study; in the collection, analyses, or interpretation of data; in the writing of the manuscript, or in the decision to publish the results.

\section{REFERENCES}

1. Bulfon C, Volpatti D, Galeotti M. Current research on the use of plant-derived products in farmed fish. Aquacult Res. 2015;46:513-51.

2. Gudding R, Van Muiswinkel WB. A history of fish vaccination: science-based disease prevention in aquaculture. Fish Shellfish Immunol. 2013;35:1683-88.

3. Magnadottir B. Immunological control of fish diseases. Mar Biotechnol. 2010;12:361-79.

4. Stratev D, Zhelyazkov G, Noundou XN, Krause RWM. Beneficial effects of medicinal plants in fish diseases. Aquacult Int. 2018;26:289-308.

5. Van Hai N. The use of medicinal plants as immunostimulants in aquaculture: a review. Aquaculture. 2015;446:8896.

6. Ahilan B, Nithiyapriyatharshini A, Ravaneshwaran K. Influence of certain herbal additives on the growth, survival and disease resistance of goldfish, Carassius auratus (Linnaeus). Tamilnadu J Vet Anim Sci. 2010;6(1):5-11.

7. Yin G, Jeney G, Racz T, Xu P, Jun X, Jeney Z. Effects of two Chinese herbs (Astragalus radix and Scutellaria radix) on non-specific immune response of tilapia, Oreochromis niloticus, Aquaculture. 2006;253:39-47.

8. Alishahi M, Soltani M, Mesbah H, Esmaeili A. Effect of oral prescription of (Silybum marianum) extract on immune response of common carp (Cyprinus carpio). J Vet Sci. 2011;66: 255-63.

9. Acar Ü, Parrino V, Kesbiç OS, Saoca C, Abbate F, Yılmaz S, Fazio F. Effects of different levels of pomegranate seed oil on some blood parameters and disease resistance against Yersinia ruckeri in rainbow trout. Front Physiol. 2018;9:596.

10. Fazio F, Laria C, Saoca C, Costa A, Piccione G, Spanò N. Effect of dietary vitamin C supplementation on the blood parameters of Striped bass Morone saxatilis (Walbaum, 1752). Turkish J Fish Aquat Sci. 2020;20:491-7. 
11. Unal F. Caryotyping and localization of giemsa $C$ banding in Sternbergia fischeriana (Herbert) Rupr. and S. candida Mathew and T. Baytop from Turkey. Cytologia. 1997;62(4):357-60.

12. Gurbuz B, Arslan N, Khawar KM, Ipek A, Sarihan EO, Ozcan S, et al. Adaptation of endemic mediterranean Sternbergia candida Mathew Et T. Baytop in the continental climate of central Anatolia Sci Hortic. 2009;123(1):99103.

13. Weniger B, Italiano L, Beck JP, Bastida J, Bergonon S, Codina C, et al. Cytotoxic activity of Amaryllidaceae alkaloids. Planta Med. 1995;61(1):77-9.

14. Baxendale IR, Ley SV, Nessi M, Piutti C. Total synthesis of the Amaryllidiaceae alkaloid (+) plicamine using solid supported reagenets. Tetrahedron. 2002;58(32):6285-6304.

15. Awad E, Cerezuela R, Esteban MA. Effects of fenugreek (Trigonella foenum graecum) on gilthead seabream (Sparus aurata L.) immune status and growth performance. Fish Shellfish Immunol. 2015;45:454-64.

16. Guardilo FA, Bahi A, Esteban MA. Effects of dietary administration of fenugreek seeds on metabolic parameters and immune status of gilthead seabream (Sparus aurata L.). Fish Shellfish Immunol. 2018;74:372-79.

17. Altunoglu YC, Bilen S, Ulu F, Biswas G. Immune responses to methanolic extract of black cumin (Nigella sativa) in rainbow trout (Oncorhynchus mykiss). Fish Shellfish Immunol. 2017;67:103-9.

18. Laith AA, Mazlan AG, Effendy AW, Ambak MA, Nurhafizah WWI, Alia S, et al. Effect of Excoecaria agallocha on non-specific immune responses and disease resistance of Oreochromis niloticus against Streptococcus agalactiae. Res Vet Sci. 2017;12:192-200.

19. Vazirzadeh A, Dehghan F, Kazemeini R. Changes in growth, blood immune parameters and expression of immune related genes in rainbow trout (Oncorhynchus mykiss) in response to diet supplemented with Ducrosia anethifolia essential oil. Fish Shellfish Immunol. 2017;69:164-72.

20. Adel M, Pourgholam R, Zorriehzahra J, Ghiasi M. Hemato-Immunological and biochemical parameters, skin antibacterial activity, and survival in rainbow trout (Oncorhynchus mykiss) following the diet supplemented with Mentha piperita against Yersinia ruckeri. Fish Shellfish Immunol. 2016;55:267-73.

21. Kakoolaki S, Akbary P, Zorriehzahra MJ, Salehi H, Sepahdari A, Afsharnasab M, Mehbari MR, Jadgal S. Camellia sinensis supplemented diet enhances the innate non-specific responses, haematological parameters and growth performance in Mugil cephalus against Photobacterium damselae. Fish Shellfish Immunol. 2016;57:379-85.

22. Gabriel NN, Qiang J, He J, Ma XY, Kpundeh MD, Xu P. Dietary Aloe vera supplementation on growth performance, some haemato-biochemical parameters and disease resistance against Streptococcus iniae in tilapia (GIFT). Fish Shellfish Immunol. 2015;44:504-14.

23. Ivanc A, Hasković E, Jeremić S, Dekić R. Hematological evaluation of welfare and health of fish. Praxis Veterinaria. 2005;53:191-202.

24. Haghighi M, Sharif Rohani M. The effects of powdered ginger (Zingiber officinale) on the haematological and immunological parameters of rainbow trout (Oncorhynchus mykiss). J Med Plant Herb Ther Res. 2013;1:8-12.

25. Ahmed I, Reshi QM, Fazio F. The influence of the endogenous and exogenous factors of hematological parameters in different fish species: a review. Aquac Int. 2020;28:869-99.

26. Acar Ü, Saoca C, Sabri Kesbiç O, Yılmaz S, Yigit M, Evren İnanan B, Fazio F. 2019. Comparative study on haematological and biochemical parameters of two wild sparid fish species. Cah Biol Mar. 2019;60:51-7.

27. Fazio F. Fish hematology analysis as an important tool of aquaculture: a review. Aquaculture. 2019;500:237-42.

28. Fazio F, Saoca C, Acar Ü, Tezel R, Çelik M, Yilmaz S, Sabri Kesbiç O, Yalgin F, Yigit M. A comparative evaluation of hematological and biochemical parameters between the Italian mullet Mugil cephalus (Linnaeus 1758) and the Turkish mullet Chelon auratus (Risso 1810). Turk J Zool. 2020;44: 22-30.

29. Lee TH, Qiu F, Waller GR, Chou CH. Three new flavonol galloylglycosides from leaves of Acacia confusa. J Nat Prod. 2000;63:710-12.

30. Anderson DP, Moritomo T, Grooth RD. Neutrophile, glass-adherent, nitroblue tetrazolium assay gives early indication of immunization effectiveness in rainbow trout. Vet Immunol Immunopathol. 1992;30:419-29.

31. Baba E, Uluköy G, Mammadov R. Effects of Muscari comosum Extract on Nonspecific Immune Parameters in Gilthead Seabream, Sparus aurata (L. 1758). J World Aquac Soc. 2014;5(2):173-82.

32. Parry RM, Chandan RC, Shahani KM. A rapid and sensitive assay of muramidase. Proc Soc Exp Biol Med.1965;119:384-6.

33. Ellis AE. Lysozyme assays. In: Stolen JS, Fletcher TC, Anderson DP, Roberson BS, Van Muiswinkel WB, editors. Techniques in Fish Immunology. 1st ed. SOS Publications, New Jersey; 1990. p. 101-3.

34. Bradford MM. A rapid method for the quantification of microgram quantities of protein utilizing the principle of protein dye binding. Anal Biochem. 1976;72:248-54.

35. Schaperclau W, Kulo H, Schreckenbach K.1991. Hematological and serological technique. In: Kothekar VS, editor. Fish disease. 2nd ed. Oxonian Press, New Delhi; 1991. p. 71-108.

36. Steinhagen D, Kruse P, Körting W. Some heamatological observations on carp, Cyprinus carpio L. experimentally infected with Trypanoplasma borreli Laveron. J Fish Dis. 1990;13:157-62.

37. Magnadottir B. Innate immunity of fish. Fish Shellfish Immunol. 2006;20: 137-51.

38. Uribe C, Folch H, Enriquez R, Moran, G. Innate and adaptive immunity in teleost fish: A review. Vet Med. 2011;56(10):486-503.

39. Whyte SK. The innate immune response of finfish e A review of current knowledge. Fish Shellfish Immunol. 2007;23:1127-51. 
40. Yildiz HY, Meric I, Ergonul MB. Changes of non-specific immune parameters in rainbow trout, Oncorhyncus mykiss after exposure to antimicrobial agents used in aquaculture. J Appl Aquac. 2009;21:139-50.

41. Fazio F, Saoca C, Perillo L, Piccione G. Relationship between non-specific immune response and body size in cultured Rainbow trout. Turkish J Fish Aquat Sci. 2019;19:71-6.

42. Secombes J. Isolation of salmonid macrophages and analysis of their killing activity. In: Stolen JS, Fletche TC, Anderson DP, Robertson BS, van Muiswinke WB, editors. Techniques in Fish Immunology. 1. SOS Publication, Fair Haven; 1990. p. 137-52.

43. Anderson DP, Jeney G. Immunostimulants added to injected Aeromonas salmonicida bacterin enhance the defense mechanism and protection in rainbowtrout (Oncorhynchus mykiss).Vet Immuno Immunopathol. 1992;34:389-97.

44. Chen SC, Yoshida T, Adams A. Non-specific immune response of Nile tilapia, Oreochromis nilotica, to the extracellular products of Mycobacterium spp. And to various adjuvants. J Fish Dis. 1998;21:39-46.

45. Nan FH, Agus Putra A, Margie B, Lee MC. The effects of Curcuma zedoaria and Zingiber zerumbet on nonspecific immune responses of grouper Epinephelus coioides. Iran J Fish Sci. 2015;14:598-611.

46. Awad E, Awaad AS, Esteban MA. Effects of dihydroquercetin obtained from deodar (Cedrus deodara) on immune status of gilthead seabream (Sparus aurata L.). Fish Shellfish Immunol. 2015;43:43-50.

47. Uribe C, Folch H, Enriquez R, Moran G. Innate and adaptive immunity in teleost fish. Vet Med. 2011;56:486-503.

48. Bilen S, Ünal S, Güvensoy H. Effects of oyster mushroom (Pleurotus ostreatus) and nettle (Urtica dioica) methanolic extracts on immune responses and resistance to Aeromonas hydrophila in rainbow trout (Oncorhynchus mykiss). Aquaculture. 2016;54:90-4.

49. Adel M, Safari R, Pourgholam R, Zorriehzahra J, Esteban MA. Dietary peppermint (Mentha piperita) extracts promote growth performance and increasethe main humoral immune parameters (both at mucosal and systemiclevel) of Caspian brown trout (Salmo trutta caspius Kessler,1877). Fish Shellfish Immunol. 2015;47:62329.

50. Ndong D, Fall J. The effect of garlic (Allium sativum) on growth and immune responses of hybrid tilapia (Oreochromis niloticus × Oreochromis aureus). J Clin Immunol Immunopathol Res. 2011;3:1-9.

51. Hajibeglou A, Sudagar M. Immune response of common Carp (Cyprinus carpio) fed with herbal immunostimulants diets. J Anim Vet. Adv. 2010;9:1839-47.

52. Takahashi JB, Takahashi L, Pilarsk F, Sebastiã F, Urbinati E. Serum bactericidal activity as indicator of innate immunity in pacu Piaractus mesopotamicus (Holmberg, 1887). Arq Bras Med Veterinaria Zootec. 2013;65:174551.

53. Dadras H, Hayatbakhsh MR, Shelton WL, Golpour A. Effects of dietary administration of Rose hip and Safflower on growth performance, haematological, biochemical parameters and innate immune response of Beluga, Huso huso (Linnaeus, 1758). Fish Shellfish Immunol. 2016;59:109-14.

54. Prasad G, Charles S. Haematology and leucocyte enzyme cytochemistry of a threatened yellow catfish Horabagrus brachysoma (Gunther 1864). Fish Physiology Biochem. 2010;36:435-43.

55. Dorucu M, Colak SO, Ispir U, Altinterim B, Celayir Y. The effect of black cumin seeds, Nigella sativa, on the immune response of rainbow trout, Oncorhynchus mykiss. Mediterr Aquacult J. 2009;2(1):27-33.

56. Kumar S, Raman RP, Pandey PK, Mohanty S, Kumar A. Kumar K. Effect of orally administered azadirachtin on non-specific immune parameters of goldfish Carassius auratus (Linn. 1758) and resistance against Aeromonas hydrophila. Fish Shellfish Immunol. 2013;34:564-73.

57. Mohamad S, Abasali $\mathrm{H}$. Effect of plant extracts supplemented diets on immunity and resistance to Aeromonas hydrophila in common carp Cyprinus carpio. Res J Animal Sci. 2010;4:26-34.

58. Nya EJ, Austin B. Development of immunity in rainbow trout (Oncorhynchus mykiss, Walbaum) to Aeromonas hydrophila after the dietary application of garlic. Fish Shellfish Immunol. 2011;30:845-50. 